Acta Universitatis Nicolai Copernici • Pedagogika XXXIV/2/2017

Nauki Humanistyczno-Społeczne • Zeszyt 440

DOI: http://dx.doi.org/10.12775/AUNC_PED.2017.014

\author{
Adela Kożyczkowska \\ Uniwersytet Gdański
}

\title{
WIEDZA O PRZESZŁOŚCI JAKO KONTEKST (DE)KONSTRUKCJI TOŻSAMOŚCI: KASZUBSKA TOŻSAMOŚĆ ZAPOŚREDNICZONA
}

\section{Wprowadzenie}

Dodejmując problem wiedzy o przeszłości - w zakresie społecznego 1 pamiętania i wiedzy historycznej - danej wspólnoty narodowej czy etnicznej, trzeba mieć na uwadze także problem tożsamości i - mniej lub bardziej świadomie - trzeba mierzyć się z pamięcią i historią jako tym, co współtworzy tożsamość. W prezentowanym tekście interesuje mnie poniekąd problem „metodologii tożsamości”, którą rozpoznawać można w związkach z pamięcią i historią.

Podjęty problem badawczy przesunął moją wypowiedź na pogranicze historii i pedagogiki. Jako autorka tekstu mam świadomość, że każda z tych dyscyplin, jakkolwiek korzysta z tej samej przestrzeni metodologii nauk humanistycznych, to jednak - ze względu na własny przedmiot badań - specyfikuje swą metodologię. Jednocześnie każda odnosząc się do wytwarzanej przez siebie wiedzy i teorii - z taką samą atencją odnosi się do efektów swych działań. Dla historii prymarne jest konstruowanie wiedzy na temat przeszłej rzeczywistości i produkowanie - jak pisze Jerzy Topolski - faktów i dziejów.

Wiedza historyczna jest ważna w procesie wytwarzania i/bądź zmiany świadomości osobistej oraz społecznej, gdyż wytwarza obiek- 
tywne ramy działania osobistego i społecznego. W tym ujęciu wszelkie konsekwencje o charakterze edukacyjnym są wtórne, ale historyk jest tego świadom. Dla pedagogiki wiedza i teorie wytwarzane w obrębie historii stanowić mogą interesujący przedmiot badań, który - nie zależnie od intencji i świadomości badacza dziejów - decyduje o politycznych relacjach władzy, relacjach społecznych, postawach wobec członków własnej wspólnoty i obcych czy wreszcie - uogólniając o kształcie tożsamości społecznych i osobistych. Inaczej ujmując: pedagodzy mogą być zaciekawieni tym, jak wiedza historyczna staje się elementem walki o władzę i jak dostarcza legitymizacji na rzecz konkretnej polityki tożsamościowej czy (wielo)kulturowej, i jak w tej opisywanej wielokrotnie przez Michaela Foucaulta relacji wiedzy-władzy używana jest edukacja, którą czyni się - mniej lub bardziej subtelnie - metodą wcielania albo nasączania umysłów konkretną interpretacją historyczną.

Egzemplifikacją do namysłu jest książka Kaszuby przez wieki. Poradnik dla nauczycieli uczących własnej historii i kultury Kaszubów autorstwa Michała Kargula i Krzysztof Kordy, którzy w notce biograficznej przedstawiają się jako historycy i pedagodzy.

Wypowiedź swą konstruuję w trzech częściach. W pierwszej sięgam do metodologii badań historycznych Jerzego Topolskiego i omawiam wiedzę historyczną, która obiektywizuje się w postaci tekstu. Interesuje mnie wiedza jako wytwór pracy historyka i jej możliwe deformacje. Ważkie z perspektywy postawionego problemu jest rozpoznanie, jak użyta przez historyka (badacza albo autora tekstu) teoria organizuje strukturę wypowiedzi. Dlatego teoria jako struktura stanowi bezpośrednio przedmiot mojego badania książki Kargula i Kordy. Ta część mojego artykułu koncentruje się na analizie i interpretacji formalnej, która bada w myśli Topolskiego tzw. wymogi formalne dla wiedzy historycznej ${ }^{1}$, która następnie użyta jest w formalnej edukacji historycznej.

W drugiej części artykułu badam wiedzę poradnika przez próbę rekonstrukcji jego struktury i przedstawiam jej trzy główne kategorie:

1 M. Januszewicz, O interpretacji, „Przestrzenie Teorii” 2013, nr 20, s. 220-221. 
„Kaszuby”, „Kaszubi” i „język kaszubski”. Metodologicznie interesuje mnie to, co Joanna Rutkowiak ${ }^{2}$ nazywa „kategoriami” jako pojęciami teoriotwórczymi. W sensie kulturowym pojęcia - z ich znaczeniami - zostają nasycone wiedzą kulturową przez sam fakt obecności w kontekście, w którym się je przykładowo umieszcza. Pojęcia ukierunkowują myślenie, dlatego że są efektem tego myślenia: decydują o interpretacji świata i jednocześnie - jako interpretacje - świat odzwierciedlają. Wybrane do prezentacji w artykule kategorie „Kaszuby”, „Kaszubi”, „język kaszubski” „otrzymują” w poradniku konkretne znaczenia, czyli wyposażone zostają w określoną wiedzę na drodze konotacji semantycznej, którą autorzy uzyskują przez kontaminację pojęć, kojarzenie słów, wpisanie w określone konteksty itp.

W tej części badania koncentruję się na analizie i interpretacji semantycznej, która polega „na odnajdywaniu, wynajdywaniu czy negocjowaniu sensu danego wytworu kultury"3. Michał Januszewicz wiąże wynajdywanie sensu z procesem transakcji tekstu i interpretacji. Oznacza to, że interpretacja zawsze jest kogoś, zawsze czegoś dotyczy, czyli zawsze coś jest jej przedmiotem ${ }^{4}$. Przedmiotem badania jest tekst, co oznacza, że każdy fenomen kultury musi być sprowadzony do postaci tekstu. Kargul i Korda nie badają bezpośrednio przeszłości, teraźniejszości czy kultury, ale ich obiektywizacje w postaci rozmaitych tekstów. Podstawą interpretacji jest rozumienie „tekstu”, które „determinowane” jest tym, jak uprzednio jest już rozumiany świat. Rozumienie tekstów jest więc jakoś motywowane, a badacz chce rozumieć to, co go bezpośrednio zainteresowało. Interpretacja objawia więc ontologię badacza, co stwarza możliwość jej rozumienia jako semiotyczno-hermeneutycznej. W ostatniej części pracy rozważam możliwą (de) konstrukcję tożsamości w kontekście wytwarzanej wiedzy (interpretacji) o przeszłości i teraźniejszości kaszubskiej. Odwołuję się do inter-

2 J. Rutkowiak, „Pulsujące kategorie” jako wyznaczniki mapy odmian myślenia o edukacji, w: Odmiany myślenia o edukacji, pod red. J. Rutkowiak, Kraków 1995, s. 14, 25-26.

3 M. Januszewicz, dz. cyt., s. 220.

${ }^{4}$ L. Pareyson, Estetyka. Teoria formatywności, tłum. K. Kasia, Kraków 2009, s. 202. 
pretacji społecznej pozwalającej rozpoznać miejsce, z którego konstruowana jest interpretacja zjawisk kulturowych. Tak ujęta interpretacja „zanurzona jest w określonej tradycji i historii interpretacyjnej”, czyli w określonej wspólnocie interpretacyjnej. To ona określa nie tylko warunki przyjęcia danej interpretacji, ale także decyduje o przekazie aksjomatów, idei, przeświadczeń, a także o użytych narzędziach na potrzeby transmisji znaczeń.

\section{Jerzego Topolskiego metodologiczne myślenie o narracji historycznej}

Jerzy Topolski swą koncepcję historii wyprowadza z autorskiego odczytania myśli Karola Marksa i rekonstruuje marksowską teorię dziejów, którą nazywa materializmem historycznym. Koncepcja dostarcza autorowi potężnego narzędzia metodologicznego, które jest odzwierciedleniem dziejów i jednocześnie pozwala badać przeszłą rzeczywistość społeczną. Jest to możliwe dlatego, że sam Marks wyprowadził pojęcia i zależności między nimi bezpośrednio z praktyki społecznej i dokonał ich uogólnień w ten sposób, że nabrały mocy filozoficznej lub ekonomicznej i społecznej (w sensie dyscyplin naukowych). Topolski kontynuował pracę Marksa, ponieważ dostrzegł w niej metodologiczną: rozpoznał, że pozwala rozumieć rzeczywistość w sposób dynamiczny i dziejowy i jednocześnie pozwala wytworzyć metodę badania dziejów człowieka i ludzi.

Ważnym obszarem metodologii Topolskiego jest zawarta w niej przestrzeń antropologiczna, która każe widzieć człowieka jako podmiot aktywny, przez swe działanie wytwarzający świat i stwarza „ramy” swego działania. I jednocześnie człowiek jest wywarzany przez ten świat i zawarte w nim ramy. Topolski zatem łącząc dzieje z działaniem człowieka, osadza swą teorię na antropologii dziejów: historia a więc także świat i jego kultura - nie jest tym, co tworzy się samo, ale to człowiek działa i jest odpowiedzialny za swą historię. Topolskiego antropologię dziejów wiązać trzeba ze zdolnością człowieka w zakre-

${ }^{5}$ M. Januszewicz, dz. cyt., s. 221. 
sach: (1) wytwarzania świadomości historycznej, jako podstawy uniezależnienia się od natury i biologii, co Topolski wiąże ze świadomością, iż natura i osobista biologia człowieka stanowią ramy działania zarówno na rzecz stwarzania kultury, jak i historii6; (2) wytwarzania i rozwoju świadomości indywidualnej i grupowej jako podstawy działań indywidualnych i grupowych, te zaś - jak pisze Topolski - są podstawą tworzenia kultury i historii ${ }^{7}$; (3) tworzenia refleksji o przyszłości, ta przez Topolskiego nazywana jest historią8; (4) tworzenia refleksji o przeszłości jako podstawy planowania działań, co Topolski nazywa hominizacją człowieka9.

Wiedza i rozwój moralny (ten przez Topolskiego rozumiany jest jako działanie na rzecz dobra ogólnego) obok świadomości i refleksji stanowią atrybuty rozumności człowieka. Topolski zwraca jednakże uwagę na wiedzę historyczną jako szczególny typ wiedzy wytwarzany przez człowieka i wspólnotę. O wiedzy tej autor pisze, że „dla strategii efektywnego działania, nie jest obojętne, do jakiej wiedzy historycznej działający się odwołuje"10. Wiedza historyczna funkcjonująca w działaniu powinna być dynamiczna i teoretyczna, powinna ujmować fakty w odniesieniu do całościowej struktury, tak by za jej pomocą można było rozpoznać dynamikę struktury procesu historycznego i rozpoznać jego mechanizmy ${ }^{11}$. Wiedza historyczna nabiera szczególnego znaczenia w odniesieniu do prawdy, która według Topolskiego wiąże się ze świadomością historyczną. Ta zaś jest zawsze świadomością historyczną danego społeczeństwa. Każde społeczeństwo posiada właściwe sobie wyobrażenie o prawdzie historycznej i to wyobrażenie konfrontuje z prawdą dostarczaną - czy też jak ujmuje to Topolski „wyprodukowaną" przez historyków ${ }^{12}$.

\footnotetext{
6 J. Topolski, Wolność i przymus w tworzeniu historii, Warszawa 1990, s. 14-15.

7 Tamże, s. 16-17.

8 Tamże, s. 12.

9 Tamże, s. 13.

10 J. Topolski, Historia i życie, Lublin 1988, s. 35.

11 Tamże, s. 35-36

12 Por. J. Topolski, Prawda i model w historiografii, Łódź 1982, s. 19.
} 


\section{Historyk jako wytwórca i wytwór dziejów}

Rozpoznanie antropologii dziejów w myśleniu Topolskiego wskazuje dwa zasadnicze wątki metodologiczne: (1) ujęcie człowieka jako tego, który wytwarza rzeczywistość, (2) ujęcie badacza (historyka) jako tego, który produkuje wiedzę o (przeszłej) rzeczywistości, którą nieustannie konfrontuje z rzeczywistością.

Badacz nie jest tym, który „odkrywa” prawdę, on tę wiedzę produkuje. Ujawnia się różnica między człowiekiem będącym badaczem a człowiekiem niebędącym badaczem: pierwszy konfrontuje „prawdę” zawartą w wyprodukowanej wiedzy z „rzeczywistością przeszłą”, drugi z własną - osobistą i społeczną - prawdą ${ }^{13}$. Rozbieżność między prawdą historyka i odbiorcy dzieł historycznych ujawnia różnice, jakie istnieją między wiedzą wytwarzaną przez historię jako dyscyplinę naukową a wiedzą społeczną, która stanowi efekt społecznego pamiętania. Jednak struktura narracji historycznej może być wytwarzana w oparciu o wiedzę inną niż naukowa. Struktura każdego tekstu naukowego stanowi jego warstwę ukrytą, która daje się rozpoznać dopiero w procesie badania tekstu, i zaświadcza o spełnieniu przez tekst postulatów metodologicznych, co z kolei przekłada się na to, że tekst albo jest prawomocny albo nie.

Struktura tekstu historycznego może być - jak dowodzi Topolski - zaczerpnięta z przestrzeni ideologicznych, mitologicznych, wiedzy potocznej, a nawet z osobistych przekonań („przeświadczeń”) autora. W takim przypadku nauka może zaledwie maskować właściwy cel powstania pracy historycznej, która pod „płaszczem naukowości” wyraża idee inne niż naukowe ${ }^{14}$ i promuje w swej warstwie mniej lub bardziej jawnej określone ideologie. Historyk powinien zatem być świadomy napięcia, jakie pojawia się między tym, co społeczne i polityczne (wiedza społeczna i ideologiczna), a tym, co naukowe (wiedza naukowa), i jednocześnie powinien być świadomy napięcia, jakie pojawia się między tym, co osobiste (wiedza prywatna), a tym, co nauko-

13 Tenże, Historia, s. 36.

14 Tamże, s. 37. 
we. Badania historyczne nie mogą być podporządkowane ideologiom, celom politycznym, prywatnym i wspólnotowym przekonaniom, nie mogą też być przestrzenią konstruowania mitów ${ }^{15}$. Co warto podkreślić, a co stanowi szczególną kłopotliwość metodologiczną historii: historia jest związana z polityką, a racje polityczne deformują teorie dotyczące przeszłej i teraźniejszej rzeczywistości społecznej ${ }^{16}$.

W wiedzy historycznej istotna jest prawomocność narracji historycznej, a nie jej wyobrażeniowa „zgodność” $\mathrm{z}$ „prawdą” historyczną, „zgodność” z rzeczywistością czy wyimaginowane „rozumienie” rzeczywistości. Stąd też w procesie produkowania wiedzy historycznej prymarnym zadaniem historyka jest „prawdziwe odtworzenie przeszłości"17. Jednakże odnoszenie narracji historycznej wyłącznie do „prawdy”, „zgodności” i „rozumienia” nie rozwiązuje problemu prawdziwości narracji historycznej, gdyż ta pod fasadą naukowości może być nośnikiem treści wygenerowanych przez ideologię, a nie naukę.

Topolski wyjaśnia, na czym polega „prawdziwe odtworzenie przeszłości”: otóż wiąże się ono z produkowaniem przez historyka narracji, której celem jest rekonstrukcja przeszłej rzeczywistości, a także konstruowanie faktów historycznych przez ich opis, realizowany w sposób zgodny z metodologią badań historycznych. To zaś oznacza, że nieprawdziwość faktów i nieadekwatna interpretacyjna w stosunku do empirii są dowodami braku należytej troski metodologicznej. W konsekwencji rozpoznaje się ten brak troski jako błąd metodologiczny, który poświadcza, że tekst historyczny nie spełnia warunków prawomocności ani prawdziwości i na tej podstawie powinien być odrzucony ${ }^{18}$.

Wytwarzanie - i jednocześnie badanie - narracji historycznej odnosi się do przywołanych kryteriów prawomocności i prawdziwości. (1) Kryterium prawomocności zakłada, że każda narracja historyczna konstruuje się na porównaniu wytwarzanej narracji do rzeczywistości, a właściwie do obrazu rzeczywistości, który został zaakceptowany przez dyscyplinę naukową, a więc przez historię jako naukę.

15 J. Topolski, Prawda i model, s. 13.

16 Tenże, Prawda i fatsz $w$ historii, Poznań 1987, s. 21-22.

17 Tenże, Prawda i model, s. 13.

18 Tamże, s. 19-21. 
Konfrontacja, by sprostać kryterium prawomocności, musi być odniesienia i do „fragmentu przeszłej rzeczywistości” i do „ogólnego jej pojmowania"19. (2) Kryterium prawdziwości obejmuje całość narracji i wiąże się z rozpoznaniem prawdziwości warstwy teoretycznej, czyli tego, co tworzy strukturę narracji. Teoria jako struktura narracji jest jakby „niewidzialną osnową”, na której badacz umieszcza pojedyncze „zdania o faktach i wyjaśnienia”. Teoria jako struktura decyduje o tym, które zdania w narracji są ważniejsze, a które mniej ważne, które są podstawowe, a które dopełniają to, co podstawowe. Użyta teoria powinna odzwierciedlać strukturę rzeczywistości, chociaż Topolski zastrzega, że teoria może mniej lub bardziej wiernie odzwierciedlać rzeczywistość, co oznacza, że narracja konstruowania na teorii może być mniej lub bardziej prawdziwa ${ }^{20}$. Teoria jako struktura decyduje więc nie tylko o selekcji, ale i o gradacji wydarzeń, na mocy których produkowane są fakty i narracja. Wybór teorii będzie zatem odzwierciedlać nie tylko rzeczywistość jako taką, lecz także przyjęte przez historyka rozumienie rzeczywistości.

\section{Świadomość metodologiczna badacza}

Topolski pisze, że nie istnieje taka teoria, która nie podlegałaby sprawdzeniu, co metodologicznie oznacza, że każda dyscyplina naukowa, jako przestrzeń wytwarzania teorii, z konieczności wytwarza także kryteria sprawdzalności ${ }^{21}$. Chodzi zatem o dwie powiązane ze sobą kwestie: (1) obiektywność badań historycznych - o czym po części już pisałam, choć nie odwoływałam się bezpośrednio do tej kategorii metodologicznej, jednak jak zauważa Topolski, nie można rozdzielić postulatu prawdziwości od postulatu obiektywności'i2; (2) świadomość metodologiczna historyka.

19 Tamże, s. 31.

20 Tamże, s. 31-37.

21 J. Topolski, Teoria wiedzy historycznej, Poznań 1983, s. 487-489.

22 Tamże, s. 494. 
Jeśli wiedza historyczna powinna być dynamiczna i teoretyczna ${ }^{23}$, to teoria powinna być realistyczna i dynamiczna, jest to związane z tym, że naukowiec konstruuje narrację historyczną, w której bada i opisuje przeszłą rzeczywistość kategoriami teorii użytej działaniu badawczym $^{24}$. Potrzebuje zatem teorii na sposób instrumentalny, a to mogą zapewnić tylko teorie bardziej ogólne i jednocześnie te, które są w ciągłym rozwoju, czyli wzbogacane są o wnioski płynące z realizowanych badań historycznych ${ }^{25}$.

Pomimo rygorystycznych kryteriów metodologicznych w zakresie używania dotychczasowej i konstruowania nowej wiedzy teoretycznej nie jest możliwe uzyskanie absolutnie prawdziwego obrazu przeszłości, tak jak nie jest możliwe uzyskanie obrazu przeszłości, który byłby całkowicie wolny od wiedzy i aksjomatów historyka. Ten wnosi do działania badawczego określony rodzaj wiedzy wstępnej i preferowany system wartości. Ta implementacja dzieje się niezależnie od tego, czy badacz jest jej świadom, czy nie ${ }^{26}$.

Odsłania się problem świadomości metodologicznej badacza dziejów. Topolski wiąże ją z wiedzą ogólną historyka decydującą o wyborze zasad metodologicznych i wartościowaniu. Ściślej ujmując: działanie badawcze realizowane jest w trzech perspektywach wiedzy: (1) ontologicznej, którą Topolski wiąże z wizją świata i człowieka; (2) metodologicznej, którą Topolski łączy z przyjętą przez historyka wizją nauki (ideałem nauki) i zasadami metodologicznymi, przy czym zasady metodologiczne są powiązane z osobistą ontologią historyka; (3) aksjomatycznej, ta zaś - zdaniem Topolskiego - decyduje o przyjętej przez historyka wizji świata i człowieka oraz nauki, a także o wybranych zasadach metodologicznych. Te trzy obszary wiedzy konstruują praktyczny model tzw. wewnętrznego intelektualnego sterowania działaniem badawczym. Immanentną częścią działania badawczego

23 J. Topolski, Historia, s. 35-36

24 Tenże, Teoria, s. 488.

25 Tamże, s. 183-188, 488-490.

26 Tamże, s. 490. 
jest realizowanie procesu poznawczego w obszarze badania (analizy i interpretacji) faktów historycznych i relacji między nimi ${ }^{27}$.

Świadomość metodologiczna jest ważna w sytuacji rozpoznawania przez historyka osobistych przeświadczeń. Te - jako wartościujący typ wiedzy - kierują badaniem, o czym wspomniałam wcześniej. Świadomość metodologiczna wiąże się zatem także z rozpoznawaniem przeświadczeń i ich wyjaśnianiem, co stanowi warunek niezbędny w procesie wytwarzania teorii. W praktyce działań badawczych wiąże się to ze świadomym i możliwie precyzyjnym działaniem poznawczym ${ }^{28}$.

\section{Egzemplifikacja: poradnik dla nauczycieli Michała Kargula i Krzysztofa Kordy*}

Poradnik dedykowany jest nauczycielom przedmiotu własna historia i kultura Kaszubów i zawiera 1/3 treści z zakresu szeroko pojmowanej kultury (w tym geografii i przyrody, które trudno do kultury wpisać wprost) ${ }^{29}$ oraz $2 / 3$ treści z zakresu historii. Na potrzeby niniejszego tekstu utrzymuję założenie Topolskiego, wskazujące metodologiczną zależność między kulturą i historią, co powoduje, że badać kulturę oznacza jednocześnie badać historię ${ }^{30}$, a w metodologii mojej pracy oznacza, że badając wiedzę o kulturze, badam wiedzę o historii.

\section{Cele i założenia poradnika}

Własna historia Kaszubów - według autorów - jest historią regionalną, a ta nie jest popularna „nawet wśród samych historyków”.

27 Tamże, s. 131-135.

28 Tamże, s. 152-157

M. Kargul, K. Korda, Kaszuby przez wieki. Poradnik dla nauczycieli uczqcych własnej historii i kultury Kaszubów, Gdańsk 2015.

29 Analiza podstaw programów przedmiotów język kaszubski i historia i społeczeństwo wskazuje, że autorzy przenieśli geografię i przyrodę Kaszub z treści programowych języka kaszubskiego. Treści te w zasadzie nie mieszczą się w zakresach treściowych pojęć „historia” i „kultura”.

30 J. Topolski, Wolność, s. 9. 
Realizacja przedmiotu może być trudna, ze względu na „właściwą selekcją ${ }^{31}$ najważniejszych zjawisk i wydarzeń z dziejów małej ojczyzny” i znalezienie „właściwej literatury” (s. 9). Z tego powodu autorzy postanowili przybliżyć nauczycielom najważniejsze zagadnienia z zakresu dziejów, tradycji i przyrody Pomorza. By zrealizować cel, autorzy: (1) dokonali właściwej „selekcji najważniejszych zjawisk i wydarzeń z dziejów małej ojczyzny”, (2) „znaleźli właściwą literaturę"; (3) dokonali wyboru najbardziej odpowiednich 30 zagadnień dla klas 4-6. W konsekwencji autorskich działań opracowano tematy w taki sposób, że „niejako naturalnie” układają się „w pewien konkretny program określający kolejność wprowadzania treści regionalnych w szkole podstawowej" (s. 9).

Analiza treści wskazuje, że autorzy dokonują selekcji ze względu na dwa rodzaje celów: (1) historyczno-świadomościowy i (2) edukacyjno-świadomościowy. Historyczno-świadomościowy cel selekcji to: najrzetelniejsze zaprezentowanie przeszłości i kultury Kaszub. Cel ten w założeniu jest osiągany przez: (1) przystosowanie "przedstawionych treści do potrzeb najważniejszych adresatów”, czyli uczniów klas 4-6 szkoły podstawowej; (2) uniknięcie pułapek ideologicznych i sporów dotyczących przeszłości Kaszub; (3) rozwijanie umiejętności interpretowania faktów historycznych i „odróżniania zdarzeń historycznych od legendarnych i mitycznych". Edukacyjno-świadomościowy cel selekcji to: pogłębienie wiedzy uczniowskiej na temat swojej małej ojczyzny. Cel ten w założeniach poradnika powinien być osiągany przez: (1) sposób przystępny i zrozumiały przekaz informacji; (2) korelowanie treści programu z treściami przedmiotu historia i społeczeństwo dla kultury polskiej, dla II etapu nauczania $^{32}$; (3) uadekwatnienie treści do potrzeb i możliwości poznawczych uczniów (s. 11).

31 Wszystkie podkreślenia w tekście - także w cytatach - są mego autorstwa.

32 Chodzi o starą podstawę programową, obowiązującą do roku szkolnego 2016-2017. 


\section{Kaszubi: przeszła i teraźniejsza rzeczywistość. Rekonstrukcja struktury wypowiedzi}

Przedmiot własna historia i kultura Kaszubów nie posiada podstawy programowej. Autorzy dla swego programu jako matrycy użyli treści podstaw programowych dla przedmiotów: język kaszubski i historia i społeczeństwo. Obie podstawy programowe są określone w stosownym rozporządzeniu Ministra Edukacji Narodowej i są wobec siebie autonomiczne, i takie powinny być także wobec programu dla przedmiotu własna historia i kultura Kaszubów. Kargul i Korda nie tyle inspirowali się obiema podstawami, ale - w deklaracji - skorelowali własny program z podstawami programowymi dla nauczania języka kaszubskiego i historii i społeczeństwa. O ile pierwsza podstawa pisana jest na potrzeby kultury kaszubskiej, o tyle druga napisana została na potrzeby kultury polskiej. Szczegółowa analiza wynikowego planu pracy (s. 13-22) wskazuje dwa typy odniesień: ogólne/całościowe i konkretne/częściowe. Co oznacza, że niektóre treści wskazanych podstaw programowych zostały całościowo przeniesione do programu Kaszuby, inne zaś częściowo.

Przeanalizowałam w układzie liniowym - od lekcji I do XXX strukturę poradnika, uwzględniając jego warstwę ideologiczną. Analiza treści pozwala rozpoznać kilka tropów.

(1) Skorelowanie programu Kaszuby przez wieki z podstawą programową historii i społeczeństwa (o czym pisałam wcześniej) wskazuje na niesamodzielność historii kaszubskiej w relacji do historii polskiej.

(2) Analiza układu treści kolejnych lekcji ujawnia gradację treści historycznych (i kulturowych) w taki sposób, że jako pierwsze prezentowane są treści historii polskiej, a dopiero jako drugie treści historii kaszubskiej. Każdy temat historyczny konstruowany jest na wiedzy z historii polskiej, która podejmuje głównie problemy (państwowe i/lub narodowe) na Pomorzu i Kaszubach. Dopiero na tej podstawie omawiane są treści, które dotyczą historii Kaszubów i/lub Pomorzan, ale w interpretacji centralnej. Zastosowana gradacja wskazuje, że ważniejsza jest historia pol- 
ska, gdyż prezentowana jest jako pierwsza i w tym układzie wytwarza kontekst dalszej interpretacji. Pozwala to rozpoznać kryterium selekcji wydarzeń i kryterium wyboru ich interpretacji, oba wynikają z przyjęcia perspektywy (kontekstu) interesu polskiego (przy czym trudno ustalić, na czym ów interes polega).

(3) Wytworzona $\mathrm{w}$ poradniku struktura wraz $\mathbf{z}$ jej kategoriami (czyli teoriotwórczymi pojęciami) ustawia konfrontacyjnie historię i język kaszubski do historii i języka polskiego. Relacja dominacji polskości nad kaszubskością osiągnięta zostaje nie tylko w wyniku określonej gradacji treści, ale też przez użycie siatki pojęciowej typowej dla polityki tożsamościowej wczesnego PRL i polityki podboju kolonialnego, który wciela/włącza/przyłączania terytoria podbite - Kaszuby - do dominium - Polski - a opowieść o autochtonach (czyli Kaszubach), ludach podbitych, snuta jest z perspektywy zewnętrznej.

(4) Wiedza o języku i kulturze kaszubskiej prezentowana jest przede wszystkim z perspektywy polonocentrycznej. Dla udowodnienia jej większej słuszności wobec perspektywy kaszubocentrycznej autorzy odwołują się do wiedzy, którą pozyskują w obszarze społecznym. W wiedzy tej dominuje społeczne pamiętanie, mity, legendy i przeświadczenia światopoglądowe niemające poparcia w badaniach empirycznych. Analiza warstwy powierzchownej i ukrytej poradnika wskazuje obecność tezy „język i kultura kaszubska są podrzędne wobec języka i kultury polskiej", co powoduje, że zawarte w poradniku znaczenia kategorii ,język kaszubski” potwierdzają podrzędność kaszubszczyzny przez jej opis za pomocą kryteriów: klasowego, lingwistycznego, użyteczności, autonomii, terytorialnego. Teza „o podrzędności języka i kultury kaszubskiej” jest uprzednia wobec narracji i w swej istocie stanowi ukryte kryterium selekcji i gradacji treści historycznych i kulturowych.

(5) Układ treści każdej lekcji wskazuje, że zagadnieniają organizujące, nasycane są wiedzą konstruującą świadomość tożsamościową. W świadomości czytelnika wytwarzany jest model tożsamości wysycany konkretną interpretacją dostarczaną przez autorów. Część metodyczna podręcznika (scenariusze zajęć) sta- 
nowi skuteczne narzędzie indoktrynacji w zakresie wszystkich tematów poradnika z wyjątkiem przyrody i geografii. Autorzy w każdym scenariuszu lekcji wyraźnie wskazują, „co i jak mówi nauczyciel". Wskazanie dotyczy nie tylko wydarzenia z przeszłości, ale także jego konkretnej interpretacji. Autorzy utrzymują dryl interpretacyjny przez informowanie nauczyciela, jak jakościowo prowadzić dyskusję z uczniami. Obok „rozmów kierowanych” (przykładowo: s. 25), w których nauczyciel „wskazuje”, „wymienia”, „przekazuje” „przypomina”, „podkreśla”, pojawiają się pozornie swobodne dyskusje, ale są one finalizowane $\mathrm{w}$ ten sposób, że nauczyciel „odbiera” z poradnika instrukcje typu: „najlepsze wypowiedzi”, „najtrafniejsze propozycje i przemyślenia” (przykładowo: s. 139) czy „w razie konieczności prowadzący koryguje zgłaszane propozycje wypowiedzi" (przykładowo: s. 107) albo „podczas burzy mózgów uczestnicy zajęć wspólnie poszukują odpowiedzi” (przykładowo: s. 69, 75, ) i „wyróżnia rozwiązania, które" (przykładowo: s. 131) wpisują się w przyjętą logikę interpretacji, „prowadzący uzupełnia” (przykładowo: s. 163), ale znów w logice przyjętej interpretacji, bądź też „prowadzący koryguje i uzupełnia ich [uczniów - A. K.] wypowiedzi" (przykładowo: s. 170). Uogólniając: autorzy konstruują swój poradnik na transmisji znaczeń, w którym nauczyciele albo przekazują określoną wiedzę, a uczniowie są jej beneficjentami, albo stawiają pytania w kontekście narzuconej przez autorów interpretacji, a uczniowie odpowiadają również w kontekście narzuconej przez autorów interpretacji.

\section{Kategorie „Kaszuby” i „Kaszubi”}

Na potrzeby niniejszej pracy wykorzystałam dwa kategorie: „Kaszuby” i „Kaszubi”. Pomocniczo sfomułowałam pytania: Kim są Kaszubi? Czym są Kaszuby? Treści poradnika pozwoliły na zrekonstruowanie przypisanych im znaczeń, które odzwierciedlają poradnikową wiedzę o Kaszubach jako ludziach i regionie. 


\section{Kim są Kaszubi?}

Treści lekcji I ujawniają, że Kaszubi są autochtonami. Pojęcie „autochton” pojawia się jako odrębne lub w konfiguracji: „autochtoniczna społeczność”, „autochtoniczna grupa słowiańska”, „grupa autochtoniczna”, „autochtoniczni mieszkańcy regionu”, „pomorska grupa autochtoniczna”. Nasycenie pojęciem „autochton” lekcji I jest tak duże (pojawia się ono 12 razy), że wytworzone zostaje przeświadczenie, iż „Kaszubi to autochtoni". Pojęcie jest utrwalane w treściach lekcji II, IV, V i zostaje przypomniane w treściach lekcji XXVII, XXIX, XXX. Stwierdzenie „Kaszubi to autochtoni” jest elementem wiedzy o: (1) terytorium (tematy: „Pomorze - nasz mała ojczyzna” i „Mieszkamy na Kaszubach”), (2) symbolach narodowych/etnicznych (temat: „Kaszubskie symbole”), (3) literaturze (temat: „Literacka historia Kaszub”), (4) polityce tożsamościowej wczesnego PRL (temat: „Ruch kaszubski po 1945”), (5) historycznych związkach Polski z Bałtykiem (temat: „Kaszubskie morze”), (6) języku kaszubskim (temat: „Historia języka kaszubskiego”).

W kontekście powyższego wydaje się, że autorzy książki Kaszubi mają wyraźne kłopot natury metodologicznej: nie rozpoznają genealogii znaczenia pojęcia „autochton”, co znaczy, że nie rozpoznają, z jakich przestrzeni teoretycznych i ideologicznych pobierają pojęcie do tworzenia struktury pojęciowej, czyli nie widzą jego teoriotwórczej mocy. Wprawdzie wydaje się, że autorzy, używając pojęcia „autochton”, są świadomi jego tożsamościowego znaczenia. Pisząc bowiem o teorii pochodzenia mniejszości na ziemiach nadbałtyckich, rozpoznają „autochtoniczność” jako „narzędzie” odróżniania członków społeczności autochtonicznych, np. „od Niemców czy od polskiej ludności napływowej, która po drugiej wojnie światowej zasiedliła tereny nadmorskie" (s. 25). Kargul i Korda zdają się jednak niepamiętać, jakie pochodzenie ma pojęcie „autochton”, które jest wytworem polityki tożsamościowej wczesnego PRL, a jego znaczenie tożsamościowe było definiowane tak, jak piszą o tym autorzy. O polityce ludnościowej pierwszych lat powojennych pisze m.in. Andrzej Sakson, który wskazuje klasyfikacyjne znaczenie pojęcia „autochton”: selekcjonowało i umożliwiało prowadzenie celowych działań o charakterze najpierw prawno-penalnym 
(rehabilitacja i weryfikacja), a następnie administracyjno-biurowym. Celem było wytworzenie nowego typu społeczeństwa, ale w taki sposób, by realizowane były potrzeby państwa, troska zaś o ludność rodzimą Ziem Odzyskanych była sprawą drugorzędną. Interesy państwa - jak zauważa Sakson - kolidowały z interesami regionu. Stopniowo państwo zaczęło dominować nad regionami ${ }^{33}$.

Wracając do treści poradnika: analizy lekcji XXVII (temat: „Ruch kaszubski po 1945 r.”) i lekcji XXVIII (temat: „Bądkowski i Solidarność") pozwalają wysunąć tezę, że autorzy dystansują się od PRL, w ten sposób że nie wiążą tego okresu w historii Polski z samą Polską. W treściach obu lekcji nie rozpoznaje się odniesień do Polski, ale są za to: „aparat państwowy” czy „władza komunistyczna”, „socjalistyczna władza”, „władze totalitarnego państwa”. Pojęcie „polska władza” pojawia się tylko jako rozróżnienie dla władzy radzieckiej w Polsce. Czytelnik może więc doświadczać swoistego dysonansu poznawczego, gdyż autorzy dystansują się od PRL i jednocześnie korzystają z siatki pojęciowej ówczesnej polityki ludnościowej. Autorzy wytwarzają też w poradniku szczególny dystans do ludności rodzimej przez nadużycie pojęcia autochton. Kargul i Korda pozycjonują Kaszubów w sposób typowy dla kolonialnych opisów etnograficznych. Dla porównania: odmienny styl narracji tworzy Sakson, który opisuje dzieje społeczności Mazurów i Warmiaków, i sporadycznie używa pojęć „ludność rodzima”, „społeczność mazurska”, „Mazurzy”, „Warmiacy” czy „grupa etniczna". To ostatnie pojęcie używane jest dla rozróżnień identyfikacji etnicznej i identyfikacji narodowościowej. Jeśli pojawia się pojęcie „autochton”, jest to wynikiem opisu działania politycznego czy przytoczenia danych statystycznych z określonego momentu realizacji polityki ludnościowej.

33 A. Sakson, Mazurzy - społeczność pogranicza, Poznań 1990, s. 74, 139, 124-140, s. 144-153. Por. także: A. Kożyczkowska, Od praktyki do teorii edukacji regionalnej. Casus kaszubskości, w: Wielokulturowość: między edukacją regionalną i edukacją międzykulturową, pod red. K. Kossaka-Główczewskiego, A. Kożyczkowska, Kraków 2015. 


\section{Czym sq Kaszuby?}

Znaczenia kategorii „Kaszuby” konstruowane są w odniesieniach do terytorium Polski w układzie temporalnym. Kargul i Korda konstruują wiedzę o Pomorzu i Kaszubach w logice pozytywnego interesu Polski. Brak jest rozpoznania wiedzy o Pomorzu i Kaszubach w relacjach do polityki niemieckiej (z wyjątkiem czasów zaboru pruskiego i II wojny światowej) czy wpływów polityki państw basenu Morza Bałtyckiego (z wyjątkiem potopu szwedzkiego). Jednocześnie autorzy produkują wiedzę w taki sposób, że usuwają z niej elementy, które są niespójne z ich wizją interesu Polski. Przykładem może być zdanie: „Po 1945 roku znaczna część Pomorza Zachodniego znalazła się w granicach Polski. Większość niemieckich mieszkańców regionu opuściła rodzinne ziemi [...]" (s. 23, 28). W tym kontekście rodzą się pytania: Dlaczego władze PRL zadały sobie tyle trudu, by dokonać selekcji ludności autochtonicznej (rodzimej) od ludności niemieckiej i polskiej ludności napływowej? Dlaczego z perspektywy historii niemieckiej mówi się nie tylko o „opuszczeniu”, ale także o „wysiedleniu” czy wręcz „wypędzeniu" ludności niemieckiej z Ziem Odzyskanych przez Polskę? Pytania pozostawiam bez odpowiedzi.

Autorzy, pisząc o Pomorzu i Kaszubach, używają pojęć typowych dla aneksji terenu w obszar innego państwa, co ma niewiele wspólnego z partnerstwem polsko-kaszubskim i ukazuje politykę polską jak politykę zaborcy. Siatka pojęciowa tworzona jest z pojęć takich jak: „podbój” (s. 68, 70, 74), „odzyskanie”, „przyłączenie” i „zwrócenie” (s. 90). Pojęcie „powrót” (s. 167, 185, 186, 188, 189, 242) pojawia się w opisach przede wszystkim sytuacji po I wojnie światowej. Dalej są pojęcia: „przyłączenie” (s. 90, 177, 189), „włączenie” (s. 189, 195), „wkroczenie” (s. 187, 188) wojsk polskich na Pomorze, „wcielenie” (s. 189, 195), „uznanie przynależności” (s. 188), „odzyskanie połączenia z ojczyzną” (s. 193) i wreszcie „wyzwolenie” (s. 189), ale tylko Czerska.

Gdyby wyłuszczyć wątek związku/związków terytorium Pomorza i Kaszub do/z terytorium Polski, to pisana przez autorów interpretacja byłaby bliższa „retoryce” kolonialnej. 
Wybrany styl narracji prezentuje ponurą tragedię, w której polskość jak fatum zawisa nad Pomorzem i Kaszubami, by w końcu zrealizować przeznaczenie: by polskie wojsko wkroczyło i wcieliło Pomorze i Kaszuby do Polski. Wyłuszczenie na potrzeby badania wizji związku terytorialnego Pomorza i Kaszub z Polską zwraca uwagę na dodatkowy problem: każdy, kto przeszedł kurs historii polskiej w zakresie szkoły średniej, pamięta z lekcji, że Pomorze zostało odzyskane i Polska ponownie zyskała dostęp do Morza Bałtyckiego po I wojnie światowej. W kaszubskim pamiętaniu i w kaszubskiej historii mowa jest o przyłączeniu Pomorza do Polski czy odzyskaniu Pomorza w wyniku działań okołowojennych $^{34}$. Z lekcji historii każdy pamięta, że proces scalania ziem w jeden twór państwowy nie odbył się w jednorazowym akcie pokonania trzech mocarstw, i choć autorzy ten proces nazywają „walką dyplomatyczną" (s. 187), to trzeba go pojmować jako proces dyplomatyczny, w którym ścierały się rozmaite racje i interesy. Stąd też rekonstrukcja Polski po I wojnie światowej rozłożona była w czasie i nie objęła wszystkich ziem przedrozbiorowych. Niemniej jednak niefortunne jest określenie, że Pomorze i Kaszuby wróciły do Polski. Gdyby zachować ten styl retoryki, to trzeba by napisać, że i Polska wróciła do Polski.

34 Taką interpretację spotkać można także w tekstach popularnonaukowych, dziennikarskich oraz w podręcznikach i książkach pomocniczych do edukacji kaszubskiej: J. Borzyszkowski, I wojna światowa i walka Kaszubów o przyłączenie Pomorza do Polski, w: tenże, Historia Kaszubów. Historiô Kaszëbów. Vademekum, tłum. J. Treder, Gdańsk 2014 s. 196. Z. Klemenczak, 93 rocznika odzyskania Pomorza Przed powrotem Polski nad morze, „Gazeta Kaszubska”, 8 luty 2013 r., http://www. gazetakaszubska. pl/42344/93-rocznica-odzyskania-pomorza-przed-powrotempolski-nad-morze (dostęp: 20.05.2017 r.). Tenże, 93 rocznica odzyskania Pomorza - Morze, polskie morze, „Gazeta Kaszubska”, 10 luty 2013 r., http://www. gazetakaszubska. pl/42524/93-rocznica-odzyskania-pomorza-morze-polskie-morze (dostęp: 20.05.2017 r.). W. Bòbrowsczi, K. Kwiatkòwskô, Zdënk z Mòrzã, w: ciż, Kaszëbsczé Abecadło. Twój pierszi elemeńtôrz, Gdańsk 2007, s. 86-89. 


\section{Kategoria „język kaszubski”}

Konstruowanie wiedzy o mowie Kaszubów i języku kaszubskim odbywa się stopniowo. Wątki pojawiają się, rozwijają i finalizują zwykle w końcowych partiach poradnika. Na potrzeby niniejszej pracy wyłoniłam wątki związane z poradnikową wiedzą o mowie Kaszubów (tam, gdzie nie uzyskała ona statusu języka) i języku kaszubskim (a więc o mowie, która uznana została za język).

Przedmiotem pierwszych dwóch lekcji jest terytorium oraz kwestia różnic kulturowych i językowych w dziejach Pomorza (s. 24). Autorzy wyróżniają Kaszubów ze względu na ich mowę i oryginalną kulturę ludową (s. 24). Poradnik wskazuje więc na dwa kryteria identyfikacji Kaszubów: Kaszuby i mowa kaszubska (s. 31). Jednak to nie Kaszubi sami się określili w swych granicach terytorialnych i językowych, ale zrobili to naukowcy. Naukowa wizja pozwoliła - według Kargula i Kordy - ustalić granice Kaszub i sklasyfikować Kaszubów w grupy etnograficzno-gwarowe. Proces ten dokonał się w XIX i XX w. (s. 31-32). Obok wizji naukowców pojawia się też populistyczna wizja typu „większość ma zawsze rację", która reorganizuje społeczność kaszubską, a właściwie powoduje erozję społeczności kaszubskiej, gdyż - jak piszą autorzy - mieszkańcy większych miast (w tym Gdańska) nie do końca identyfikują się z kaszubszczyzną.

Stanowisko „większość ma zawsze rację” wynika - zdaniem autorów - z tego, że ok. 233 tys. osób identyfikuje się z kaszubszczyzną, a w Gdańsku mieszka ok. 460 tys. osób, wobec tego Kaszubi są mniejszością i w „regionie znajdują się na słabszej pozycji”. Dlatego też interes Kaszubów chroni Ustawa z dnia 6 stycznia 2005 r. o mniejszościach narodowych i etnicznych oraz języku regionalnym (s. 32).

Przywołuję ten fragment wypowiedzi, gdyż analiza układu treści poradnika sugeruje, że wiedza o terytorium, mowie/języku i populacji kaszubskiej przygotowuje kontekst dla wiedzy o języku kaszubskim. Do wątku tego wrócę w dalszej części tekstu. W tym miejscu muszę jednakże poczynić uwagę metodologiczną. W poradniku można rozpoznać dwa podstawowe typy wiedzy: naukową i społeczną. Wyraźnie daje się wyodrębnić etapy ich konstruowania i etapy zastosowania 
jako argumentacji na rzecz konkretnej tezy lekcji, a w konsekwencji całościowej tezy książki: „język i kultura kaszubska są podrzędne”.

\section{Wiedza naukowa}

Wiedza naukowa konstruowana jest na klasyfikacji i tezie strukturalnie zorientowanej dialektologii polskiej, wedle której kaszubski jest dialektem polskim bądź dialektem języka polskiego, choć autorzy w warstwie powierzchownej nie piszą o kaszubskim jako dialekcie. Użyte jednak kryteria klasyfikacji mowy Kaszubów i języka kaszubskiego są kryteriami lingwistycznymi, które odnosząc kaszubski mówiony do literackiej polszczyzny, otwierają drogę innym konfrontacyjnym odniesieniom. Przykładowo odniesienie języka kaszubskiego do terytorium polskiego konstruuje wiedzę o języku kaszubskim jako regionalnym. Odniesienie historii kaszubskiej do historii polskiej konstruuje wiedzę o historii polskiej jako centralnej dopełnionej historią peryferyjną, czyli kaszubską. Identyfikacja kaszubska konstruowana jest przez mowę i jej łączenie z terytorium, którego granice zakreślili naukowcy w wyniku użycia klasyfikacji strukturalno-dialektalnych. W naukowym wyobrażeniu Kaszub i kaszubszczyzny Kaszubów sprowadza się do społeczności autochtonicznej konstruowanej na mowie. Konsekwencją naukowego wyobrażenia Kaszubów i ich kultury są wewnętrze klasyfikacje społeczności kaszubskiej, oparte również na kryteriach lingwistycznych. Gwary kaszubskie decydują o opisie etnograficznym.

\section{Wiedza społeczna}

Wiedza społeczna jest konstruowana m.in. na liczbach i populizmie typu „większość ma zawsze rację”. Przykładowo w przytoczonym fragmencie dotyczącym tego, że 233 tys. Kaszubów identyfikuje się z liczbą mieszkańców Gdańska, autorzy nie wskazują źródeł pochodzenia danych. Można jednak rozpoznać, że pobrali je z Narodowego Spisu Powszechnego (NSP) z 2011 r., według którego właśnie 233 tys. osób deklaruje „przynależność do Kaszubów”: w tym ok. 216 tys. osób deklaruje polsko-kaszubską identyfikację, a 16 tys. osób wyłącznie ka- 
szubską ${ }^{35}$. Tymczasem raport GUS z 2015 r., w części poświęconej metodologii opracowania danych pozyskanych drogą NSP w zakresach identyfikacji narodowo-etnicznej, wyznania czy języka ojczystego bądź języka domowego, zwraca uwagę na dwie kwestie: pierwsza związana jest $\mathrm{z}$ użytą metodą protezowania braku danych $\mathrm{w}$ formularzach spisowych, druga wiąże się z tym, że dane pozyskane metodą spisu powszechnego zostały uogólniane (wedle prawideł statystycznych) i odniesione do populacji wszystkich Polaków. Obliczenia bazują albo na deklaracjach pozyskanych bezpośrednio drogą spisu, albo na informacjach pozyskanych metodą imputacji danych ${ }^{36}$. Formularze spisowe zawierały więc braki w zakresie danych, pomimo że NSP z 2011 r. był metodologicznie (i propagandowo) lepiej przygotowany niż spis z 2002 r., i pozwolił rozpoznać większą liczbę deklaracji w zakresie identyfikacji kaszubskich. Dla porównania: zgodnie ze spisem powszechnym z 2002 r. tylko 5 tys. osób wskazało identyfikację kaszubską ${ }^{37}$. Jednak ani dane spisu z 2002 r., ani dane spisu z 2011 r. nie odnoszą wskazanych liczb do całej populacji Kaszubów. Stąd istotna rozbieżność między wynikami NSP z 2002 r. i 2011 r. a rezultatami badań z lat 1997-2004, które zrealizował Jan Mordawski, a które objęły swym zasięgiem cały obszar zamieszkiwany przez Kaszubów na Pomorzu Gdańskim. Mordawski ocenił - na podstawie badań - liczbę Kaszubów i osób z częściowym rodowodem kaszubskim na 566737 osób ${ }^{38}$.

Jak się wydaje, trzeba racjonalnie uznać, że dane Narodowego Spisu Powszechnego są tylko danymi tego spisu. Zebrane zostały w celu rozpoznania struktury populacji polskiej - bardziej mimo wszystko jakościowo niż ilościowo - i jego niewątpliwą zaletą jest nie tyle wskazanie, „ilu jest” Ślązaków czy Kaszubów, ile ujawnienie trendu, że wspólnota polska (jako państwowa) składa się także z osób o innej niż polska

35 Struktura narodowo-etniczna, językowa i wyznaniowa ludności Polski. Narodowy Spis Powszechny Ludności i Mieszkań 2011, Warszawa 2015, s. 30; http:// stat. gov.pl/files/gfx/portalinformacyjny/pl/defaultaktualnosci/5670/22/1/1/ struktura_narodowo-etniczna. pdf (dostęp: 20.05.2017).

36 Tamże, s. 14-28.

37 Tamże, s. 40.

38 J. Mordawski, Statystyka ludności kaszubskiej. Kaszubi u progu XXI wieku, Gdańsk 2005, s. 41-44. 
identyfikacji narodowościowej. Trzeba chyba mówić o tym, że obywatele wspólnoty polskiej zaczynają być świadomi swych różnic kulturowych i nie wstydzą się ich ujawniać. Bezpieczniej metodologicznie jest traktować wyniki spisu właśnie w taki sposób, zwłaszcza że zawierały one poważne braki w zakresie deklaracji narodowo-etnicznych, językowych i wyznaniowych, które uzupełniono w drodze imputacji danych ${ }^{39}$.

Tymczasem autorzy traktują dane spisu jak "twardą rzeczywistość społeczno-demograficzną", co pozwala im manipulować wypowiedziami, a właściwie wypowiedziami jako zdarzeniami językowymi, które odbiory przedstawiają się jako zdarzenia społeczne. Autorzy używają w swej wypowiedzi liczb, w taki sposób, jakby były one typowymi danymi statystycznymi, gdy tym czasem trzeba je traktować inaczej. Użycie jednak liczb stanowi częsty sposób „uprawomocnienia" wypowiedzi. Stąd też autorzy budują w rzeczywistości pseudonaukowy kontekst wypowiedzi, która jawi się jak zdarzenia społeczne już przez sam fakt liniowego ustawienia jej elementów w tekście. Uzyskana w ten sposób kontaminacja wygląda następująco: większość ma zawsze rację $\rightarrow$ deklarujących przynależność do Kaszubów jest ok. 233 tys. osób $\longrightarrow$ mieszkańcy Gdańska to 460 tys. osób $\rightarrow$ kaszubska mniejszość w regionie znajduje się na słabszej pozycji.

Liniowe ustawienie treści wytwarza przeświadczenie: jeżeli większość ma zawsze rację i jeżeli Kaszubi stanowią mniej więcej tyle, ile stanowi połowa mieszkańców Gdańska, to Kaszubi są mniejszością i są oni na słabszej pozycji w regionie. Zastosowana kontaminacja jawi się jako obiektywnie prawdziwa i wytwarza przeciwstawne „mądrości”: (1) trzeba działać, by Kaszubi nie byli na słabszej pozycji w regionie; (2) nie warto działać, bo Kaszubi są na słabszej pozycji w regionie, a ich świat kaszubski jest „małym światem kaszubskim”, którego tylko poeci nie chcą zamienić na inny (s. 146). Zwłaszcza „mądrość” typu drugiego, łatwo zmienia się $\mathrm{w}$ kaszubskiego upiora Niewarto, który opisywany był przez Aleksandra Majkowskiego ${ }^{40}$. Wedle tradycji jest to negatywne przeświadczenie obecne w osobistej i wspólnotowej

39 Struktura narodowo-etniczna, s. 25.

40 A. Majkowski, Żëcé i przigodë Remusa. Zvjercadło kaszubskji, opr. i przypisy J. Treder, wstęp. J. Borzyszkowski, A. Kuik-Kalinowska, J. Treder, Gdańsk 2010. 
świadomości Kaszubów, które demotywuje do działania na rzecz kaszubszczyzny. Niewarto odbiera siłę i moc sprawczą w walce o zachowanie i rozwój języka i kultury kaszubskiej.

\section{Wiedza o języku kaszubskim}

Zrekonstruowany kontekst stanowi element wzoru kulturowego, w obrębie którego wywarzana jest wiedza o języku kaszubskim. Szczegółowa analiza treści książki Kaszubi przez wieki prowadzi do wniosku, że wątek wiedzy o języku kaszubskim jest wieloznaczny, a każde znaczenie konstruowane jest na innym kryterium. Wyłoniłam następujące kryteria: klasowości, lingwistyczne, użyteczności, autonomii, terytorialne. Na ich podstawie zrekonstruowałam znaczenia języka kaszubskiego w książce Kaszuby przez wieki: (1) język kaszubski jak(o) mowa ludowa (kryterium klasowe); (2) język kaszubski jak(o) wariant języka polskiego (kryterium lingwistyczne); (3) język kaszubski jak(o) polski patriotyzm (kryterium użyteczności); (4) język kaszubski jak(o) odrębny język słowiański (kryterium autonomii); (5) język kaszubski ja$\mathrm{k}(\mathrm{o})$ język regionalny (kryterium terytorialne).

Język kaszubski jak(o) mowa ludowa. Kaszubi są wyrazistą grupą autochtoniczną (s. 24), która wytworzyła w ostatnich dwóch stuleciach oryginalną kulturę ludową (s. 24). Mowa Kaszubów jest językiem ludowym, a mowa Polaków - językiem standaryzowanym, czyli „książkowym” (s. 126). Wynika z tego, że Kaszubi rozumieją język polski, nawet jeśli nim nie mówią, dlatego nauczanie powinno odbywać się przy użyciu polskich książek (s. 126). Ale to ludowość kaszubszczyzny pozwala dotrzeć do ludności wiejskiej (s. 188).

Autorzy konstruują klasową relację między kaszubskim i polskim, ale kaszubski wiążą z klasą chłopską, a polski z klasami wyższymi, a przynajmniej wykształconymi. Tym samym Kargul i Korda wywarżają i potwierdzają klasowe uwarunkowania językowe, co - w przypadku języka kaszubskiego - poświadcza jego negatywny odbiór jako języka chłopskiego i wiejskiego, a także języka osób niewykształconych. Wytworzone w poradniku przeświadczenie umacnia zatem w świado- 
mości nauczycieli i uczniów małą wartość języka kaszubskiego, czym demotywować może do podjęcia czy kontynuacji nauki.

Język kaszubski jak(o) wariant języka polskiego. Mowa Kaszubów jest częścią polskiej idei narodowej, która dodatkowo związana jest z katolicyzmem. Dowodem tego związku jest hymn Marsz kaszubski Hieronima Derdowskiego (s. 55, s. 59).

Jak piszą autorzy, Pomorze ma tylko dwa języki narodowe: niemiecki i polski (s. 121). Języki te „walczą” o Kaszubów w „sferze religii”. Ci Kaszubi, którzy ulegli językowi niemieckiemu w wyniku oddziaływań ewangelicyzmu, zostali wynarodowieni (s. 122), czyli zgermanizowani. Ci zaś, którzy posługiwali się językiem polskim przez wpływ katolicyzmu, doświadczyli „duchowego i intelektualnego rozwoju kaszubszczyzny" (s. 122), ale w obrębie polskiej idei narodowej (s. 55, 59, 122). Autorzy zauważają jednak, że formalne dominacje języków niemieckiego i polskiego nie pozwoliły na przekształcenie się języka kaszubskiego w język państwowy (s. 247). Tym samym - jak się wydaje - można uznać, że państwowość niemiecka wraz z państwowością polską nie pozwoliły na wykształcenie się państwowości kaszubskiej.

Relacja kaszubski - polski opiera się na gradacji: język kaszubski jest ludową odmianą języka polskiego (s. 126). Kaszubszczyzna jest zatem jednym z wariantów polszczyzny (s. 153), co oznacza, że kaszubski jest jednym z wariantów języka polskiego. Kaszubski jest „piękną gwarą” polską (s. 180) i dlatego narzecze kaszubskie powinno zawsze stawiane do literackiego języka polskiego jako narzecze (s. 181). Językiem przestrzeni publicznej jest język polski (s. 137, 138, 153, 155, 181). Kaszubi zaś to Polacy, posiadający polską tożsamość (s. 153, 204, 248). Jednak nie do końca, gdyż Kaszubi są szczepem polskim (s. 180). Ojczyzną Kaszubów jest Polska (s. 181), gdyż Kaszuby to część Polski (s. 188), a co „kaszubskie, to polskie” (s. 181). Oznacza to, że edukacja Kaszubów powinna odbywać się w języku polskim (s. 126, 153), ponieważ mową ojczystą Kaszubów jest mowa polska (s. 58, 153 ), czyli język polski (s. 153). Dlatego podstawowym celem regionalnych działaczy powinno być nauczenie Kaszubów, by poprawnie posługiwali się językiem polskim (s. 248). 
Wypowiedź autorów wskazuje, że choć język kaszubski i język polski są użytkowane przez zwyczajnych Kaszubów, to nie Kaszubi decydują o tym, który język jest dla nich ważniejszy. Nie oni również decydują o statusie swego języka tylko „naukowcy i ludzie kultury”, którzy „wciąż dyskutują na temat relacji łączących język kaszubski i polszczyznę" (s. 249). W tej warstwie rozumienia języka kaszubskiego autorzy unikają pojęć „dialekt polski” czy „dialekt języka polskiego” w stosunku do mowy kaszubskiej. Dialektalny typ zależności kaszubski-polski jest starannie skrywany pod pojęciami „wariant języka polskiego”, „piękna gwara” czy „narzecze polskie”. Analiza treści poradnika ujawnia jednak typowe dla strukturalnej dialektologii konfrontacyjne ustawienie kaszubszczyzny jako dialektu do polszczyzny w jej standardzie literackim.

Język kaszubski jak(o) polski patriotyzm. Kaszubi i kaszubskość to synonimy Polaka i polskości w sytuacjach szczególnego zagrożenia politycznego, które w poradniku „zwykle” wiąże się z obroną Polski i polskości przed żywiołem germańskim czy też niemieckim. Stąd Kaszubi są obrońcami słowiańszczyzny „w czasach germańskiego naporu" (s. 55) i w tym kontekście mowa Kaszubów zmienia się w język słowiański.

Kaszubi byli obrońcami języka polskiego - w czasie zaborów, gdy polski został ostatecznie usunięty z dydaktyki szkolnej. Stali się oni obrońcami ojczystej mowy, czyli języka polskiego, i jako obrońcy ojczystej, polskiej mowy przystąpili do strajków szkolnych (w latach 1906-1907). Kaszubi, broniąc mowy polskiej, zmieniają się w obywateli, którzy doświadczają intelektualnego i patriotycznego przebudzenia w polskości (s. 135). Kaszubi jednak już wcześniej - wedle narracji Kargula i Kordy - się budzili - w okresie powstania listopadowego. To przebudzenie „dało” Kaszubom poczucie przynależności narodowej (polskiej) i wolności państwowej (polskiej; s. 136). Później Kaszubi przebudzili i zajęli się konspiracją niepodległościową w czasie Wiosny Ludów. Przy tej okazji autorzy fabularyzują Floriana Ceynowę i z jednego zdarzenia, którego - co prawda omal nie przypłacił życiem - czynią esencję jego biografii. Konstruowana przez Kargula i Kordę narracja przypomina poetyką historyczną powieść w stylu płasz- 
cza i szpady, w której bohater raz jest buntownikiem, raz spiskowcem, a raz patriotą. Nie jest to wyłącznie sprawa przypadkowości użytych słów, ale kontekstów, w których bohater podejmuje działania. Stąd Ceynowa raz jest kaszubskim buntownikiem, raz kaszubskim spiskowcem, ale - gdy zajmują go bezpośrednio sprawy polskie - zmienia się w patriotę (s. 136). „Pozostając jeszcze przez krótką chwilę” w zasięgu poetyki powieści płaszcza i szpady, trzeba dopisać morał: zabór pruski przysłużył się sprawie polskiej, gdyż - wedle „historii” opowiadanej przez Kargula i Kordę - trzy razy obudził Kaszubów i pchnął ich „W stronę polskości” (s. 138), przez co „ukształtował ich świadomość narodową" (s. 138) i spowodował "narodziny polskiego patriotyzmu na Kaszubach" (s. 139).

Autorzy konstruują wiedzę, w której wzorem polskiego patriotyzmu staje się biografia Ceynowy. Sam Ceynowa jest w tradycji i kulturze kaszubskiej uznawany za budziciela świadomości kaszubskiej i „ojca” piśmiennictwa kaszubskiego. Tymczasem w opowieści Kargula i Kordy jest co prawda nadal budzicielem świadomości, ale jest to świadomość polska. Stąd autorzy rozpoznają jego działania jako prace na rzecz języka kaszubskiego i jako wyraz sprzeciwu wobec germanizacji. W wyważanej interpretacji celem działania Ceynowy jest nie budzenie świadomości tożsamości kaszubskiej, ale świadomości tożsamości słowiańskiej, która konstruuje się na dialekcie pomorskim, jako starej mowie słowiańskiej, która nie jest zepsutą i nieautentyczną polszczyzną (s. 146).

Zgodnie z wypowiedzią Kargula i Kordy Ceynowa - a później i Derdowski rozwijali odrębność kaszubskiego języka literackiego jako metody obrony przed germanizacją, a nie jako sposobu konstruowania związków z Polską (s. 146). Kaszubi to dzielni Polacy, których mowa jest gwarową odmianą języka polskiego, i dlatego najważniejszą sprawą Kaszubów jest nauczenie się posługiwania poprawnie polszczyzną (s. 248). Całość wątku domyka przekonanie, że Kaszubi jako Polacy są tymi, którzy bronią narodowych, czyli polskich wartości (s. 248).

Sprawa nie jest jednak prosta, bo Kaszuba jako polski patriota powinien udowodnić dwie kwestie: (1) poprawność swej polszczyzny, (2) użyteczność swej kultury i języka jako metody walki z naporem germańskim. Pierwsze wiąże się także z gotowością poświęcenia życia 
i wolności tak, jak robiła to inteligencja polska (s. 201-202, 229-230) w obliczu ekspansji faszystowskich Niemiec albo w dobie komunistycznej władzy. Drugie - powoduje, że Kaszubi stają się dobrymi obrońcami Polaków przed Niemcami, z racji utrwalonego w ich kaszubskiej świadomości mitu „odwiecznej wrogości Polaków z Niemcami” (s. 55). Mocną stroną polskiego patriotyzmu Kaszubów jest świadomość, że powinni zasłużyć się Polsce, i móc coś zaoferować mieszkańcom innych regionów Polski (s. 199).

Kaszubski jak(o) odrębny język słowiański. Kaszubi mają pochodzenie słowiańskie (s. 24, 31) i w konfrontacji z „germańskim naporem” stają się obrońcami słowiańszczyzny na Pomorzu (s. 55). Język kaszubski jest dialektem pomorskim, „starą mową słowiańską, a nie zepsutą i nieautentyczną polszczyzną" (s. 145). Jako samodzielny język słowiański - „mowa kaszubska jest bogatym językiem” (s. 145-146). I choć rozwój dialektu pomorskiego został zahamowany przez polszczyznę i niemiecczyznę (s. 247), to kaszubszczyznę do rangi pełnoprawnego języka podniósł Ceynowa. To on, „zaczął domagać się uznania podmiotowości Kaszubów w sensie politycznym i kulturowym" (s. 247). Zdaniem autorów Ceynowa stworzył „ideowe i naukowe fundamenty pod przyszłą rehabilitację kaszubszczyzny" (s. 248). Z kolei Stefan Ramułt uznał język kaszubski za odrębny język słowiański, który może być językiem tekstów literackich (poezja i proza; s. 248). To zdolność wytworzenia języka literackiego zaświadcza o odrębności kaszubszczyzny (s. 248). To odrębność języka kaszubskiego - jak piszą autorzy - motywowała do prac nad jego kodyfikacją (s. 248).

Kultura i język kaszubski spełniły więc kryteria autonomicznego języka słowiańskiego, chociaż - jak piszą autorzy - aspiracje do uznania autonomii języka kaszubskiego sięgają (w okresie powojennym) 1946 r. (I Kongres Kaszubski), a ich intensyfikacja nastąpiła po 1989 r. W rozumieniu Kargula i Kordy najistotniejszym potwierdzeniem statusu autonomii języka kaszubskiego było: (1) wprowadzenie jego nauki do szkoły (s. 249) oraz (2) otoczenie kaszubszczyzny w państwie polskim opieką prawną i instytucjonalną w ustawie z 2005 r. (s. 249).

Tylko pozornie w tej interpretacji języka kaszubskiego chodzi o jego odrębność. „Początek” wiedzy o języku kaszubskim jak(o) odrębnym 
konstruowany jest na odniesieniu do słowiańskiego terytorium językowego, „koniec” zaś - na odniesieniu do polskiego terytorium administracyjnego. Autorzy dokonują przesunięć: (1) od opisu języka kaszubskiego przez kryterium lingwistyczne do opisu języka kaszubskiego przez kryterium terytorialne; (2) od rozpoznania mowy Kaszubów przez wiedzę o dialektach do rozpoznania mowy Kaszubów przez wiedzę prawną.

Kaszubski jak(o) język regionalny. Pozornie poradnik prezentuje język kaszubski jak(o) regionalny w odniesieniu do Ustawy z 2005 r. o mniejszościach narodowych, etnicznych oraz języku regionalnym (s. 32, 249). Według autorów koncepcja kaszubskiego jako języka regionalnego pojawiła się już w XVI w. za sprawą Lutra i reformacji. Kargul i Korda dokonują zmiany interpretacji języka kaszubskiego przez podstawienie w idei protestanckiej (koniec XVI w.) pojęcia „język regionalny" w miejsce ,język narodowy". Dzięki temu wytwarzają hipotezę: „Reformacyjne ideały mogły przyczynić się do dynamicznego rozwoju języków regionalnych na Pomorzu [co wedle autorów mogło się wydarzyć już w połowie XVII w.]" (s. 122). W lekcji XXX autorzy zmieniają hipotezę w tezę: „luterańska doktryna” wprowadziła język regionalny „do liturgii i codziennego życia wiernych” (s. 250). Przy czym za sprawą tytułu podrozdziału „Początki języka kaszubskiego” (s. 250) wywarzają przekonanie, że język kaszubski od swego początku, czyli od XVI w. „był językiem regionalnym ” (s. 250).

Kargul i Korda odnieśli język kaszubski do administracyjnego terytorium państwa polskiego już na przełomie XVI i XVII w. Dokładnie takie samo kryterium odniesienia jest obecne w Ustawie o mniejszościach narodowych i etnicznych oraz o języku regionalnym z 2005 r. i traktuje ono język kaszubski jako część administracyjnego terytorium Polski. Jest to wytwarzanie zależności kulturowej przez konfrontacyjne ustawienie języka (jako wartości submisyjnej) do terytorium (jako wartości nadrzędnej): w tym przypadku o statusie języka decyduje terytorium, a nie społeczność, która się nim posługuje. Jednocześnie w układzie język-terytorium pominięta zostaje kwestia tożsamości kulturowej. Wspomniana ustawa nie chroni tożsamości kaszubskiej (co oznacza, że nie chroni kultury kaszubskiej), tylko język kaszubski, 
tym samym implicite traktuje Kaszubów jak Polaków (w sensie narodowości, a nie obywatelskości) mówiących po kaszubsku.

Rozpoznać można przesunięcie w czasie początku konstruowania układu język-terytorium: z przełomu XX i XXI w. do przełomu XVI i XVII w. W ten sposób Kargul i Korda próbują - świadomie bądź nie - zmienić kontekst interpretacyjny kultury kaszubskiej, przez co legitymizują proces przemiany Kaszubów w Polaków mówiących po kaszubsku.

\section{(De)konstrukcja tożsamości - dyskursywna etniczność. Poszukiwanie konkluzji}

Wojciech Kalaga, przyglądając się związkom pamięci, interpretacji i tożsamości, udowadnia - po raz kolejny w humanistyce - tezę, że interpretacja jest tym, co buduje tożsamość, i tym, co prowadzi do (samo)świadomości. Jeśli interpretacja jest budowniczym, to pamięć jest budulcem tożsamości. Pamięć jako sposób istnienia jest jednocześnie symboliczną obiektywizacją doświadczenia zbiorowego i osobistego, przez co decyduje o tym, jak człowiek jest w świecie, i o tym jak ten świat (roz)poznaje. I choć pamięć i tożsamość „spotykają się” we wspólnym działaniu, to interpretacja jest osobistym działaniem człowieka i jest ona uwarunkowana kulturowym uniwersum, w którym człowiek żyje. Badając zatem związki pamięci i interpretacji, Kalaga postuluje, by mieć na względzie i to, co osobiste, i to, co zbiorowe ${ }^{41}$. Choć Kalaga i Topolski lokują się w odmiennych tradycjach teoretycznych, to wspólną częścią ich koncepcji myślowych jest odniesienie do poznania, które wiąże się z antropologicznym ujęciem tego procesu - rozumienia i interpretowania (u Kalagi) lub opisu (u Topolskiego) który jest wynikiem działania człowieka. Efektem poznania - w dużym uproszczeniu - u Topolskiego jest narracja historyczna, a Kalagi - tekst, w którym znak otrzymuje znaczenie lub je zmienia. W obu koncepcjach myślowych idzie o stworzenie ram działania/poznania

41 W. Kalaga, Pamięć, interpretacja, tożsamość, „Teksty Drugie” 2012, nr 1-2, s. $59-62$. 
i wytwarzanie tożsamości. Związek między tożsamością osobową i społeczną jest oczywisty: pierwsza nie istnieje bez drugiej, druga nie istnieje bez pierwszej.

Proces poznawania jest dochodzeniem do rozumienia, które zapośredniczone jest w interpretacji ${ }^{42}$. I pamięć społeczna, i historia istnieją jedynie jako interpretacje ${ }^{43}$. W przypadku pamięci zbiorowej dość łatwo o interpretacyjne manipulacje. Pamięć zbiorowa (re)konstruowana jest w celowościowych procesach (za)dawania wspólnocie tych interpretacji, które powinny być pamiętane przy jednoczesnym działaniu na rzecz tego, co ma być zapominane. Przeszłość wydaje się jednowarstwowa dla interpretacji tych zdarzeń, które mają być pamiętane, i równocześnie wydaje się zamknięta zarówno dla tych interpretacji zdarzeń, jak i dla samych zdarzeń, które nie powinny/nie mogą być przechowywane $\mathrm{w}$ pamięci wspólnotowej. To stąd zbiorowe zapominanie zdarzeń i świadome „wymazania lub zepchnięcia w niebyt tych interpretacji, które w lokalnym uniwersum winny stanowić ważny moment tożsamości, ale które dla tej tożsamości mogą być bolesne lub destrukcyjne" ${ }^{\prime 44}$. Układ pamiętanie-zapominanie-niepamiętanie stanowi szkielet pedagogii pamiętania, a ta w swej naturze wspiera politykę pamięci. Z kolei w wiedzy historycznej łatwo o możliwe deformacje, które są efektem używania przez historyka rozmaitych typów wiedzy w procesie badania (analizy i interpretacji) przeszłej rzeczywistości. Tym, co powinno chronić wiedzę historyczną przed świadomymi i nieświadomymi manipulacjami opisu/interpretacji, jest metodologia badań historycznych i sprzężona z nią świadomość metodologiczna badacza.

Utopijnie można oczekiwać, że historia, która przecież „należy do wszystkich i do nikogo”, powinna być obiektywna i tym samym nieza-

42 Tenże, Mgławice dyskursu. Podmiot, tekst, interpretacja, Kraków 2001, s. 60-61.

43 Pisałam o tym: A. Kożyczkowska, Społeczne i osobiste „pamiętanie” jako kontekst „rozumienia” czy „kłopot metodologiczny”. Badania biograficzne $w$ środowiskach zróżnicowanych kulturowo, w: Z teorii i praktyki badań międzykulturowych. Dylematy metodologiczne, pod red. T. Lewowickego, A. Różańskiej, U. Klajmon-Lech, Cieszyn-Toruń 2016.

44 W. Kalaga, Pamięć, s. 71. 
angażowana tożsamościowo ${ }^{45}$. I choć istnieje wielość historii, bo istnieje wiele narodów i grup, które chcą swą historię pisać, to jest jednak jedna historia, „W której fakty pozyskane z wielości historii uplasował historyk. Lecz fakty te są pustą abstrakcją, która w nikim nie budzi emocji i o której nikt nie pamięta, ponieważ oczyszczono ją starannie z odniesień i pamięci”"46. Historia - jak pisze Jan Assmann - zaczyna się w miejscu, w którym kończy się pamięć społeczna, tradycja i inne przestrzenie związane z pamiętaniem społecznym, np. mity o prapoczątku. Historia koncentruje się na wydarzeniach i procesach, które rozpoznawane są jako ważkie dla przemian czy biegu dziejów. Historia dokonuje homogenizacji przeszłości, w wyniku czego niweluje różnice, reorganizuje fakty, łącząc je jako znaczące dla ludzkości ${ }^{47}$.

Pamięć jest konkretna nie tylko przez jej zapośredniczenie w czasie i miejscu, ale i w konkretnej tożsamości ${ }^{48}$. Jest wiec własnością żyjących i jako taka nie może być uniwersalna, a jedynie zbiorowa i motywowana „partykularnymi perspektywami” grup społecznych ${ }^{49}$. Co oznacza, że pamięć przypisana jest do wspólnoty, do konkretnego czasu, miejsca oraz tożsamości i odnosi się do teraźniejszości w rozumieniu realnej, żywej grupy społecznej. Stąd grupy społeczne konstruują się jako wspólnoty pamięci, dla których istotne są dwa aspekty przeszłości: jej trwałość i swoisty charakter. Wspólnota pamięci stanowi przestrzeń, w której wytwarzana jest „świadomość tożsamości w czasie": selekcja faktów z przeszłości/teraźniejszości do (za)pamiętania odbywa się „starannie”, a jej kryteriami są „odpowiedniość, podobieństwo, ciągłość" ${ }^{50}$. W tym też sensie Maurice Halbwachs pisze o ramach pamięci, takich jak przestrzeń, czas, środowisko czy spójność - i o treściach, które determinowane są teraźniejszością i społeczną decyzją o tym, „co” ma być zapomniane, i o tym, „co i jak” ma być pamięta-

45 A. Assmann, Przestrzenie pamięci. Formy i przestrzeni pamięci kulturowej, tłum. P. Przybyła, w: Pamięć zbiorowa i kulturowa. Wspótczesna perspektywa niemiecka, pod red. M. Saryusz-Wolskiej, Kraków 2009, s. 127.

46 J. Assmann, Kultura pamięci, tłum. A. Kryczyńska-Pham, w: tamże, s. 75

47 Tamże, s. 74-76.

48 Tamże, s. 71.

49 A. Assmann, dz. cyt., s. 127.

50 J. Assmann, dz. cyt., s. 70-72. 
ne. Stąd też uczestnik wspólnoty odtwarza swe wspomnienia pod jej presją ${ }^{51}$. I jakkolwiek to teraźniejszość decyduje o tym „co" i „jak” trafia do pamięci społecznej, to pamięć - jak pisze Ewa Hałas - musi być zorientowana na teraźniejszość i także na przyszłość, gdyż to pamięć decyduje o transmisji znaczeń w przyszłość. Pamięć przygotowuje „jakby" grunt pod nowe wydarzenia włączane do pamięci społecznej w przyszłości ${ }^{52}$. To ona będzie organizowała doświadczanie teraźniejszości i przyszłości ${ }^{53}$. To zaś co przenika do pamięci społecznej przemienia się w nauczanie i nabiera sensu oraz staje się częścią systemu symbolicznego wspólnoty ${ }^{54}$.

Pytanie zatem o książkę dydaktyczną jest ważkie - nie zależnie od tego, czy będziemy mówić o podręczniku, książce pomocniczej czy poradniku metodycznym dla nauczycieli - gdyż podręczniki szkolne zaliczane są do sfery oficjalnego przekazu ${ }^{55}$. Oczekiwania zatem wobec książki do historii mają charakter metodologiczny: wiedza powinna być wiedzą naukową (Topolski) i niezaangażowaną tożsamościowo (Aleida Assmann). Tymczasem analiza książki Kargula i Kordy pozwala zobaczyć ją jako książkę z zakresu pamięci społecznej. Jest ona oczywiście pisana jako książka do historii, ale działa jak książka do fundowania pamięci społecznej. Jest zaangażowana tożsamościowo i korzysta z metod konstruowania wiedzy społecznej (w tym potocznej), a także z technik edukacji dyrektywnej, które zabezpieczają autorską interpretację przed nauczycielskimi i uczniowskimi „zniekształceniami”. Wyłonione na potrzeby badania kategorie „Kaszuby”, „Kaszubi” i ,język kaszubski” pozwoliły rozpoznać poradnikowe znaczenia tychże i zrekonstruować najbardziej podstawową osnowę tekstu, czyli jego tożsamościowotwórczy szkielet, który rozpoznać można w dwóch zasadniczych opisach (wraz z ich ketgoriami): (1) to-

51 M. Halbwachs, Społeczne ramy pamięci, tłum. M. Król, Warszawa 2008, s. $123,154,170-171,385,430-431$.

52 E. Hałas, Przez pryzmat kultury. Dylematy badań nas współczesnościa, Warszawa 2015, s. 136.

53 J. Assmann, dz. cyt.

54 M. Halbwachs, dz. cyt., s. 431.

55 Por. J. Assmann, dz. cyt., s. 83. 
pografii przeszłości Kaszubów, która jest rekonstruowana przez pojęcie przestrzeni; (2) etnografii języka Kaszubów, która jest rekonstruowana przez pojęcie języka.

\section{Topografia przeszłości}

Kaszuby - jako teren - konstruują Kaszubów jako ludzi z Kaszub. Przeszłość udowodniła, że terytorium Kaszubów jest jednocześnie terytorium Polaków. Związki terytorialne kaszubsko-polskie są określane pojęciami „podbój”, „włączenie”, „przyłączenie” i odzwierciedlają kolonialną zależność między peryferiami/końcem świata polskiego a centrum/środkiem świata polskiego. Oczekiwać można - od poradnika do nauczania historii własnej Kaszubów - większego nasycenia treściami historycznymi, co w odniesieniu do terytorium będzie się wiązało z eksponowaniem historycznych wyznaczników przestrzeni kaszubskiej. Tymczasem przestrzeń Kaszub sprowadzona została do areny interesów polskich, a Kaszubi do zawsze walczących z wrogami Polski, głównie z Niemcami. Brak w narracji historycznych miejsc spornych czy trudnych dla relacji kaszubsko-polskich: przykładowo mówiących o tym, że rycerstwo kaszubskie brało udział w bitwie pod Grunwaldem w 1410 r., ale po stronie zakonu krzyżackiego. Wśród treści historycznych tylko raz pojawia się określenie „książęta kaszubscy” (s. 81). Autorzy nie używają także kaszubskich nazw dla historycznych terytoriów Pomorza i Kaszub, w zamian utrwalają nazewnictwo typowe dla polskiej narracji o ziemiach pomorskich i kaszubskich. Takie zabiegi pozwalają wytworzyć wraże, że historyczne Kaszuby to Pomorze Zachodnie i Pomorze Gdańskie, gdyż inne ziemie to tylko „w rzeczywistości obszar [...] w przeszłości dość zróżnicowany narodowościowo" (s. 58). Pomorze Zachodnie zostało zgermanizowane i tym samym odkaszubione, Pomorze Gdańskie znalazło się w dominium polskim, w zasięgu polskiej idei narodowej i polskiego obszaru językowego, ale wedle autorów nie zostało spolonizowane ${ }^{56}$. Historyczne czy kultu-

56 O praktykach polonizacji Pomorza i Kaszub (przykładowo) pisze Daniel Kalinowski: D. Kalinowski, Stuszna wojna na Pomorzu. Augustyn Necel i pisar- 
rowe idee, które prezentują stanowisko inne niż przyjęty przez autorów „interes polski”, są degradowane przez użycie wartościowania: np. mity historyczne wytworzone przez Derdowskiego (prezentują stanowisko polonocentryczne) wpłynęły na świadomość historyczną, a nawet na tożsamość historyczną Kaszubów (s. 55-56, 57-58, 106). Mity historyczne wytworzone zaś przez Majkowskiego (prezentują stanowisko kaszubocentryczne) są fałszowaniem historii (s. 56, 58).

W konstruowanej narracji historycznej autorzy znoszą różnicę między przeszłością i wiedzą o przeszłości, przez co sprowadzają przeszłość do tego, „co było naprawdę”, czyli do prawdy obiektywnej. Prawdziwość potwierdzona zostaje przede wszystkim tym, że autorzy - jako doktorzy historii i pedagodzy (tak się prezentują w notce biograficznej) - zamknęli ją w poradniku do nauczania historii własnej Kaszubów. Drugim sposobem legitymizacji „prawdziwości prawdy” jest użycie tytułów naukowych i nazwisk osób uznanych za autorytety w zakresie badań nad dziejami Pomorza i Kaszub: Gerarda Labudy, Józefa Borzyszkowskiego i Cezarego Obracht-Prondzyńskiego.

Autorzy kompensują niedostatek historycznych wskaźników opisu terytorium wskaźnikami lingwistycznymi, które pozyskano ze strukturalnie ujętej dialektologii polskiej i użyto jak kryteria interpretacji. Stąd topografia przeszłości zdaje się balansować między tym, co historyczne, a tym, co lingwistyczne. Jednak zbliża się swymi pojęciami do etnografii języka Kaszubów, w jej kolonialnej wersji, w której Kaszubi to autochtoni (dzicy?), a ich ziemia została podbita i włączona do dominium polskiego. Kaszubi jako autochtoni - po ich sklasyfikowaniu - poddani zostali cywilizowaniu, czyli nauczaniu języka polskiego (albo niemieckiego, jeśli weszli do dominium niemieckiego). Instytucją, która odpowiedzialna była/jest za cywilizowanie Kaszubów, jest szkoła, która zawsze uczy Kaszubów języka państwowego, w obrębie którego Kaszubi się znajdują: albo języka niemieckiego, albo polskiego. Każde państwo przez jego i szkoły - wcześniej czy później - próbuje przejąć kontrolę nad językiem Kaszubów na mocy przejęcia kontroli

stwo zaangażowane, w: Region a tożsamości transgraniczne. Literatura. Miejsca. Translokacje, pod red. D. Zawadzkiej, M. Mikołajczyk, K. Sawickiej-Merzyńskiej, Kraków 2016. 
nad terytorium. W najlepszym wypadku pozwala się mówić Kaszubom w domu po swojemu, a w kościele i innych publicznych miejscach po polsku (albo po niemiecku). Autorzy zauważają, że dwa silne języki i dwie silne państwowości przeszkodziły w rozwoju państwowości kaszubskiej, tym samym uniemożliwiły powstanie kaszubskiego języka państwowego. Może to znaczyć, że położenie Kaszub sprzyjało temu, by Kaszubi raz po raz byli poddawani polityce kulturowej: a to niemieckiej, a to znów polskiej.

\section{Etnografia języka}

Analiza struktury tekstu pozwoliła zrekonstruować poradnikową wiedzę o języku kaszubskim jako wieloznaczną. Język kaszubski jest przestrzenią pulsowania znaczeń, co można by uznać za atut książki, gdyby autorzy w świadomy sposób wskazali, że w przestrzeni publicznej dostępnych jest kilka (co najmniej dwa) ujęć języka kaszubskiego. Tymczasem książka dedykowana nauczycielom tego nie czyni. A zatem semantyczna (kulturowa) interpretacja kategorii ,język kaszubski” pozwoliła rozpoznać jego wieloznaczność za pomocą kryteriów, na których organizowała się konkretna wiedza o języku kaszubskim. I tak: (1) kryterium klasowe było podstawą wyodrębnienia rozumienia języka kaszubskiego jak(o) mowy ludowej; (2) kryterium lingwistyczne - pozwoliło rozpoznać język kaszubski jak(o) wariant języka polskiego; (3) kryterium użyteczności - dało możliwość zrekonstruowania rozumienia języka kaszubskiego jak(o) polskiego patriotyzmu; (4) kryterium autonomii - dało impuls do rekonstrukcji rozumienia języka kaszubskiego jak(o) odrębnego języka słowiańskiego; (5) kryterium terytorialne stanowiło podstawę rozumienia języka kaszubskiego jak(o) języka regionalnego.

Badanie głębszej warstwy tekstu, czyli przejście od (analizy i) interpretacji semantycznej do (analizy i) interpretacji społecznej pozwoliło odsłonić pojęcia, które ukryto pod kryteriami organizującymi wiedzę o języku kaszubskim. Są to: (1) ludność języka polskiego $\leftarrow$ jak(o) wytwór kryterium klasowego $\rightarrow$ rozumienie języka kaszubskiego jak(o) mowy ludowej. (2) Język polski $\leftarrow$ jak(o) wytwór kryterium lin- 
gwistycznego rozumienie języka kaszubskiego jak(o) wariantu języka polskiego. (3) Polska (państwo i ludność polska innych regionów) jak(o) wytwór kryterium użyteczności $\rightarrow$ rozumienie języka kaszubskiego jak(o) patriotyzmu polskiego. (4) Polska (państwo) $\leftarrow$ jak(o) wytwór kryterium autonomii $\rightarrow$ rozumienie języka kaszubskiego jak(o) odrębnego języka słowiańskiego. (5) Polska (państwo) $\leftarrow$ jak(o) wytwór kryterium terytorialnego $\rightarrow$ rozumienie języka kaszubskiego jak(o) języka regionalnego.

Etnografia języka pozwala rozpoznać - w myśleniu Kargula i Kordy - model kaszubskości powiązany z językiem polskim i terytorium polskim. W jego logice Kaszubi są Kaszubami za sprawą posługiwania się językiem kaszubskim i zamieszkiwania na terenie Kaszub, i są jednocześnie Polakami, ponieważ kaszubski jest jak język polski, a Kaszuby są Polska. Ujawnia się podwójne zapośredniczenie: pierwsze w języku i kulturze kaszubskiej, drugie w języku i kulturze polskiej. Języki i kultury nie są względem siebie symetryczne, dlatego też zapośredniczenia mają odmienne znaczenia dla tożsamości kaszubskiej.

Badanie tożsamości zapośredniczonych wymaga więcej niż opisu socjologicznego podmiotów uczestniczących w działaniach hegemonicznych. Tego typu interpretacje pozwalają co prawda rozpoznać tożsamość jako konstrukt wytworzony społecznie i rozumiany przykładowo jako tożsamość etniczna, jak to ma miejsce w przypadku Kaszubów. Tożsamości zapośredniczone wymagają badania nie jako gotowe wytwory, ale badać trzeba logikę, która je „ustanawia” i doprowadza do ich „rozpadu”. Istotne jest formalne rozpoznanie warunków, w których logika ustanawiania i rozpadu tożsamości „wchodzą ze sobą w związki" "57.

Badanie tożsamości kaszubskiej przez logikę jej ustanawiania i rozpadu oraz ich związki pozwala rozpoznać szczególne uwikłanie tożsamości kaszubskiej w to, co kaszubskie, i w to, co polskie. Żadnej z tych przestrzeni nie da się zredukować ani tym bardziej wyelimino-

57 E. Laclau, Tożsamość $i$ hegemonia: rola uniwersalności $w$ ustanawianiu logiki politycznej, tłum. S. Królak, w:, Przygodność, hegemonia, uniwersalność: wspótczesne debaty na lewicy, pod red. J. Butler, E. Laclau, S. Žižka,Warszawa 2014, s. 67-68. 
wać, ponieważ wyznaczają granice tożsamości jako niemożliwe i zarazem konieczne do jej osiągnięcia. Granice zaś (de)konstruują to, że: Kaszubi są Kaszubami i jednocześnie Kaszubi są jak Polacy. Kaszubi nigdy nie osiągną pełni kaszubskiej, bo będąc jak Polacy, nie mogą całkowicie ustanowić tożsamości kaszubskiej. I jednocześnie Kaszubi nigdy nie osiągną pełnej tożsamości polskiej, bo będąc Kaszubamii, nie mogą całkowicie ustanowić tożsamości polskiej. Dobrze oddaje to Günter Grass, który pisze: „Tak to już jest z Kaszubami [...]. [...] bo my za mało polscy jesteśmy i za mało niemieccy, bo jak ktoś jest Kaszubą, nie wystarcza to ani Niemcom, ani Polakom. Ci zawsze dokładnie chcą wiedzieć, co jest co!"58.

Mogłoby się wydawać, że tożsamość kaszubska ma ostre granice, gdyż konstruowana jest na kaszubskim kryterium etniczno-językowym. Zapośredniczenie w kulturze i języku kaszubskim jest tym, co ustanawia, a nawet legitymizuje logikę kaszubskości. Jednocześnie granice tożsamości kaszubskiej granice są rozmywane, gdyż jest ona jednocześnie konstruowana na polskim kryterium narodowościowo-językowym. Zapośredniczenie w kulturze i języku polskim prowadzi do rozpadu tożsamości kaszubskiej i pozwala legitymizować logikę polskości typu: Kaszuba to Polak mówiący po kaszubsku. Tożsamość kaszubska konstruuje się na związkach logiki ustanawiania (= kaszubskość) i logiki rozpadu (= polskość). Tylko tak może się wytwarzać potencjał emancypacyjny jako kryterium wywarzania tożsamości dyskursywnej: której logika ustanawiania (kaszubskość) jako sprzeciw i dążenie do partycypacji hegemonicznej, potrzebuje do swego urealnienia logika rozpadu (polskości), która jest opresyjna wobec kaszubskości.

Ustanawianie przestrzeni dyskursywnej (z jej wiedzami i typowymi dla niej etykami) jest wytwórcze dla tożsamości społecznej i osobowej, która (re)konstruuje się jako efekt swej dekonstrukcji. Podmiot jako taki jest niezniszczalny, a dekonstrukcja go nie znosi, ale na nowo wypełnia jego tożsamość treścią. Dzięki temu zyskuje on nową świadomość: własnej konstrukcji, uwikłania w relacje władzy i opresji, a także swej dyskursywnej natury. Tak ujęta tożsamość kaszubska

${ }^{58}$ G. Grass, Blaszany bębenek, tłum. S. Błaut, Kraków 2004, s. 404. 
z konieczności kwestionować musi oba uniwersa kulturowe: i kaszubskie, i polskie: nie mogąc się wchłonąć w oba jednocześnie i uzyskać pełni dwóch tożsamości jednocześnie, nie może również stać się częścią tylko jednego uniwersum. Tożsamość zapośredniczona w kaszubskość i polskość jednocześnie nie może być już tylko autonomiczna albo tylko podległa. Wynika to z faktu, że tylko jako nie w pełni autonomiczna, czyli nie w pełni ustanowiona (kaszubska) i jednocześnie tylko jako nie w pełni uległa, czyli nie w pełni rozpadu (polska) może się zabezpieczyć przez ciągle czającą się groźbą oskarżenia o separatyzm i przed stale obecną groźbą marginalizacji Kaszubów z Kaszub, mówiących po kaszubsku. Tylko jako podwójnie zapośredniczona tożsamość kaszubska może się reprodukować, bo nie skutkuje to koniecznością rewizji opisów świata kaszubskiego, który ciągle przecież jest światem kaszubskim i jednocześnie jest jak świat polski.

\section{Streszczenie}

WIEDZA O PRZESZŁOŚCI JAKO KONTEKST (DE)KONSTRUKCJI TOŻSAMOŚCI: KASZUBSKA TOŻSAMOŚĆ ZAPOŚREDNICZONA

Autorka podejmuje próbę rozpoznania pamięci społecznej i wiedzy historycznej jako szczególnej „metodologii tożsamości etnicznej”. W tym sensie tożsamość etniczna konstruuje się jako wspólnota pamięci. Autorka analizuje podręcznik do historii własnej Kaszubów i rozpoznaje w nim model tożsamości kaszubskiej jako podwójnie zapośredniczoną: raz w kulturze i języku kaszubskim, innym razem w kulturze i języku polskim.

Słow a klu c z owe : pamięć społeczna; wiedza historyczna; tożsamość kaszubska; historia własna Kaszubów 


\section{Summary}

KNOWLEDGE OF THE PAST AS THE CONTEXT OF IDENTITY (DE)CONSTRUCTION: THE KASHUBIAN IDENTITY OF THE MEDIATED

An attempt is made by the author to recognize the problem of social memory and historical knowledge as special "methodology of ethnic identity". It this sense ethnic identity is the community of memory. The author analyses the textbook/handbooks for to Kashubian history. The author recognize the Kashubian identity model as two mediations: first in Kashubian culture and language, secondly in Polish culture and language.

Key w ord s: social memory; historical knowledge; Kashubian identity; the history of Kashubians 
